\title{
ATTITUDES TOWARDS INCOME INEQUALITY IN TURKEY
}

\author{
Dr. Öğr. Üyesi Ömer Limanı \\ Düzce Üniversitesi \\ Akçakoca Bey Siyasal Bilgiler Fakültesi \\ ORCID: 0000-0002-6897-4253
}

\begin{abstract}
The purpose of this paper is to reveal factors that affect attitudes towards income inequality in Turkey by using World Values Surveys dataset over the period 1990-2011. Unlike previous studies on Turkey, this paper has employed ordered logistic regression with the wider period. Two separate estimations have been run using different explanatory variables. In the first estimation, findings have demonstrated that financial satisfaction of households, religion and political ideology are crucial factors in the attitude creation process. In the second estimation, trust variables have been run with traditional control variables such as sex, age, education, and marital status. People who trust armed forces, police, European Union, and government support larger income differences almost in all years. Individuals who trust labour unions prefer more equality as expected. Findings reveal that ideologies and religious affiliations of voters are determinative in the development of policies to combat income inequality, among other factors mentioned. In this context, it can be said that there is a strong connection between the concepts of religion, ideology, and justice which is mentioned together with the idea of inequality.
\end{abstract}

Keywords: Attitudes, Income inequality, Logistic regression, Redistribution preferences, Turkey

\section{Türkiye'de Gelir Eşitsizliğine Yönelik Tutumlar}

\section{Öz}

Bu makalenin amacı 1990-2011 dönemi World Values Surveys veri setini kullanarak Türkiye'deki gelir eşitsizliğine yönelik tutumları etkileyen faktörleri ortaya koymaktır. Türkiye üzerine yapılmış daha önceki çalışmalardan farklı olarak bu çalışmada daha geniş bir zaman dönemi ile sıralı lojistik regresyon kullanılmıştır. Farklı açıklayıcı değişkenler kullanılarak iki farklı tahmin gerçekleştirilmiştir. Birinci tahminden elde edilen bulgular hanehalkı finansal tatmininin, dinin ve siyasi ideolojinin tutum yaratım sürecinde kritik faktörler olduğunu ortaya koymuştur. Ikinci tahminde güven değişkenleri cinsiyet, yaş, eğitim ve medeni durum gibi geleneksel değişkenler ile analize koşulmuştur. Kolluk kuvvetlerine, polise, Avrupa Birliği'ne ve hükümete güvenen kişiler neredeyse her yılda daha büyük gelir farklılığını desteklemektedir. Işçi sendikalarına güvenen bireyler beklendiği üzere daha fazla eșitliği tercih etmektedir. Bulgular, adı geçen diğer faktörlerin yanında, gelir eşitsizliğiyle mücadeleye yönelik politikaların geliştirilmesinde seçmenlerin ideolojilerinin ve dini turumlarının belirleyici olduğunu ortaya koymaktadır. Bu bağlamda, eşitsizlik kavramıyla birlikte anılan adalet ile din ve ideoloji kavramları arasında güçlü bağlantılar olduğunu söylenebilir. Türkiye

Anahtar Sözcükler: Tutumlar, Gelir eşitsizliği, Lojistik regresyon, Yeniden dağılım tercihleri,

* Makale geliş tarihi: 25.05.2017

Makale kabul tarihi: 14.03.2018 


\section{Attitudes Towards Income Inequality in Turkey}

\section{Introduction}

Economists have investigated the trade-off between equality and efficiency for a long time. Some of them have supported the government intervention for equality and others have opposed and stand up for the efficiency of the economy. In this stage, the behaviour of government is influenced by voters in the modern democracies. If people prefer an equal society, then, they vote for the party which supports equality. Thus, understanding the factors that affect the attitudes of individuals towards income inequality is vital for economists and governments. For this reason, scholars have tried to uncover factors, which determine people's attitudes towards income inequality and redistribution preferences all over the world.

The early attempts to examine preferences towards redistribution have been made by Romer (1975) and Roberts (1977). Later, these models have been extended by Meltzer and Richard (1981). This classic model is based on median voter approach and assumes that individuals consider their current situation in income distribution. Individuals who are below the mean income will support redistribution while individuals who are above the mean income will oppose redistribution. Median income becomes relevant when income distribution is already right-skewed. That is, if income is unevenly distributed across individuals, median income will be smaller than mean income. Therefore, median voter will determine whether there will be redistribution. So, larger the gap between median and mean income, more support for redistribution. It may be simply said that individuals support redistribution as long as income transfers increase their income. Empirical evidence from traditional approach is controversial. Alesina and Rodrik (1994), Milanovic (2000), Fong (2001), Guillaud (2008) and Isaksson and Lindskog (2009) have found supportive evidence for median voter approach while Alesina and Glaeser (2005) and Rodrigiuez (1999) have not found any supporting evidence.

Researchers have focused on other determinants, such as expectations, culture, religion and group behaviour, because of the contradictory findings. Individuals who are below the mean income might oppose redistribution because of the prospect of upward mobility. So, individuals who expect to move to the 
upper side of the income distribution will not support redistribution. This idea roots in Hirschman and Rothschild (1973). They have called this situation as "tunnel effect" and have illustrated by using traffic jam. If you got stuck in a traffic jam and saw that next line move after a while but you could not, you first would probably wait some time and expect to move a bit later. That is, relativity becomes important in this idea. People compare themselves with other people and create their expectation. "If some people can move to the upper side of income distribution, why can others move not?" statement looks very familiar. Benabou and Ok (2001) have enhanced this model and have developed theoretical underpinnings. Fong (2001), Alesina and La Ferrara (2005), Rainer and Siedle (2008) and Neustadt and Zweifel (2009) have found supportive evidence for the prospect of upward mobility hypotheses. So, how do individuals create their expectations?

According to Piketty $(1995,1996)$, people pay attention to past experiences and observe society whether it rewards effort. This puts "beliefs" in the play; if people believe in that society rewards effort, then, there will not be preferences towards redistribution. Alesina and La Ferrara (2005) and Benabou and Tirole (2006) have developed theoretical models that analyse the role of effort and luck in the individuals' success. That is to say, justice and fairness perception influence individuals' beliefs. This is interesting because if there is a consensus about effort is the sole way to get success in society, then, there will be no redistribution. Fong (2001), Alesina and La Ferrara (2005) and Alesina and Angeletos (2005) have shown that beliefs about the role of effort and luck in individuals' success are important determinants of the preferences for redistribution.

Redistribution demand may be assessed in the context of insurance mechanism. Unemployed individuals have little or no income. So, they will be more vulnerable to adverse events and be a proponent of redistribution. However, self-employed individuals will be less vulnerable. Therefore, they will oppose redistribution. The similar situation may occur in marriage. Single people probably will be more vulnerable than married individuals will. Insurance mechanism also works in religious relationships. Members of a religious group might tend to accept their situation or look after each other (Neher, 2011). According to the different viewpoint, redistribution might crowd out religious attendance and charities (Neustadt, 2011). Other non-economic determinants, such as political regime (Alesina and Fuchs-Schündeln, 2007), racial and group relations (Alesina et al., 2001; Roemer and Straeten, 2005; Luttmer, 2001), and envy (Fehr and Schmidt, 1999), also influence preference for redistribution. Finally, the statute may play a significant role in preference for redistribution. Individuals who are below mean income might also oppose redistribution to stop 
"poorer" individuals' mobility. Thus, the quality of matching in marriage market might be preserved.

Following the referred theoretical literature, this paper aims to investigate the socioeconomic and individual factors determine the attitudes towards income inequality in Turkey. The motivation behind this investigation is based on rising income inequality in the global world and notable income inequality score of Turkey. In order to reduce income inequality, policymakers should understand not only the effect of macroeconomic variables such as inflation, international trade or unemployment, but also the socioeconomic situation of individuals and their normative beliefs. The contribution of this paper to literature is twofold. First, previous studies on Turkey have used single year data. This article has used five-time points that are between 1990-2011. We expect that this time range will show the behavioural differences between different time points in Turkey. Second, factors, which are related to social capital, have also been put in the model and analysed separately. To trust institutions, police, press or legal system might be an indicator of attitudes towards income inequality. These factors have been ignored by previous studies.

The remainder of this paper is organised as follows. Section 2 reviews the previous empirical studies. ${ }^{1}$ Data and methodology that are used in this article are given in Section 3. Estimation results for Turkey can be found in Section 4. Finally, Section 5 presents the conclusion.

\section{Empirical Literature}

Fong (2001) has examined the question that why people do support redistribution or oppose it in the context of beliefs about sources of success in life. Using Gallup Poll Social Audit Survey for 1998 and General Social Survey for several years, Fong (2001) has found that self- and exogenous- determination beliefs have enormous and significant effects on preferences for redistribution in the United States of America. Self-determination indicates that individuals have controls that determine the outcomes. Exogenous-determination states that the things beyond the control of individuals determine outcomes. According to Fong (2001, p. 242), "people are reciprocal or hold strong principles of equity" because of the reciprocity, altruism or to prevent social problems.

Corneo and Grüner (2002) have analysed individuals' opinion on government should take on the responsibility to reduce the income gap between wealthy and poor or not. They have categorised the determinants of individuals'

1 For more comprehensive review, from different perspectives, please see Piketty (1995), Neher (2011), Clark and D'Ambrosio (2015), and Costa-Font and Cowell (2015). 
opinions in three effects: i) homo economics effect, ii) public values effect, and iii) social rivalry effect. The first effect represents the position of individuals in income distribution. The second effect refers beliefs to sources of success in life. Final effect stands for relative living standards of individuals. Using Social Inequality II Module of International of International Social survey Programme for 1992, Corneo and Grüner (2002) have found that their three categories have vast and significant effects, with expected signs, on the opinion about whether the government should reduce inequality or not.

Alesina and La Ferrara (2005) have estimated the determinants of preferences for redistribution by using General Social Survey and Panel Study of Income Dynamics over the period 1978-1991. The primary goal of this study is to focus on the role of income expectation. To this end, authors have used mobility indexes and utilised transition matrices. Results have shown that individuals who expect a better life in the future do not support redistribution. This study also indicates that people who have high job prestige do not support redistribution. Alesina and Giuliano (2009) have also estimated the determinants of preferences for redistribution by using General Social Survey and World Value Surveys over the period 1972-2004 and found similar results with Alesina and La Ferrara (2005).

Keely and Tan (2008) have also estimated the determinants of preferences for redistribution by using General Social Survey over the period 1978-2000. Unlike previous studies, Keely and Tan (2008) have used classification and regression trees \& random forests methodologies. They have concluded that opinions of individuals about redistribution are heterogeneous according to the race and socioeconomic variables. They have argued that existing theoretical explanations do not tell everything. Their finding is not consistent with existing approaches.

As we have stated in the introduction section, cultural factors also influence preferences for redistribution. Luttmer and Singhal (2011) have mainly considered cultural determinants and have used European Social Survey for 32 countries over the period 2002-2007. The study has shown that preferences of individuals towards income distribution are affected by the preferences in the country where they were born. Economic-politic interest and social environment cannot explain choices of people entirely. Similarly, Dahlberg et al. (2012) have focused on one of the most important social phenomenon; immigration. Using Swedish National Election Studies Programme for 1982, 1985, 1988, 1991 and 1994, they have shown that increment in the migrant ratio in the population increases opposite opinions about social aid. This might mean that people might support redistribution in favour of groups those they belong. 
Until now, we have presented empirical literature from different countries or country groups other than Turkey. Now, the studies that are mainly focused on Turkey will be reviewed. There are very few studies that examine preferences for redistribution in Turkey. As far as we know, there are only three studies and first is Arıkan (2013). Using European Social Survey for 2008, she has analysed the effects of values and religiosity on preferences for redistribution. She has also used ordered logit procedure as much of the previous studies. Arıkan (2013) has shown that being politically rightist and conservative decreases the probability of support redistribution when they are compared with individuals who are in opposite spectrum of these variables. Similarly, religious people do not support redistribution as much as less religious individuals. Note that interpretation should be made according to the reference category.

Other two studies, which focus particularly on Turkey, are Karayel (2015) and Karayel (2016). Karayel (2015) has estimated determinants of preference of redistribution by using Social Inequality Module 2009 of International Social Survey Program. She has recoded ordered dependent variable as a binary variable and has run a standard logistic regression. We believe in that this is a problematic approach to the analysis of ordered variable. Ordered variables should be recoded at least as "ordered variable" with less scale as we have done in this study. Karayel (2015) has found that individuals who believe that hard work brings success are more supportive government intervention to close the income gap. This is interesting because previous studies have found contradictory findings. Individuals who frequently attend religious services and who never attend religious services are less supportive than individuals who visit once a week or three or two times a month for governmental intervention. These interesting findings might occur because of the recoding ordered variable as binary. Except for Aegean, all regions are less supportive when they are compared with reference category, İstanbul. Karayel (2016) has used World Values Survey for 2007 and 2011 and again have recoded ordered variable as binary. Still, people who believe that hard work brings success, who are religious or rightist support income equality. In all education categories, except for upper, individuals are less supportive of income equality. The Mediterranean, East Central and South Eastern Anatolia are more supportive than İstanbul.

\section{Data and Methodology}

In this study, we have used World Values Survey for 1990, 1996, 2001, 2007 and 2011 to examine preferences for redistribution in Turkey. World Values Survey is the long-standing survey for Turkey compared with its counterparts such as European Social Survey (only two years; 2004 and 2008) and European Values 
Studies (only one year; 1999). Therefore, it has been selected for our main database in this study. Variables, which we have employed in estimations, have been selected by following previous theoretical and empirical studies. We have benefited mainly from Neher (2011) and Guillaud (2013). Each variable is defined in the following lines.

Our dependent variable represents individuals' preferences for redistribution. The original dependent variable is Likert-type scaled and varies from 1 to 10.1 means that income should be more equal and 10 implies that there should be more significant differences between incomes as incentives. In the estimation steps, we have faced perfect prediction problem. Hence, we have recoded our dependent variable and have created a new ordered dependent variable as follows. ${ }^{2}$ We have recoded original dependent variable as 1 if individuals report the values which smaller than 5 . These people can be evaluated as the proponent of equality. 5 and 6 have been recoded as 2 . These people can be seen as neutral or indifferent. Respond values that bigger than 6 have been coded as 3. These individuals can be evaluated as the opponent of equality. Similar recoding strategy has been used for 1-10 scaled independent variables.

We have used standard socioeconomic variables such as sex, marital status, employment status, education, age and age squared and region. Beside these standard variables, we have also added several variables following previous theoretical explanations. We know from the traditional approach to the preference for redistribution that economic situation of individuals affects the preference for redistribution. We expect to catch this effect by using satisfaction from financial position of the household. This variable originally varies from 1 to 10.1 means not at all and 10 means completely satisfied. It has been recoded as follows; 1 if individuals mainly do not satisfy where they report less than 5, 2 if individuals moderately satisfy where they report 5 or 6 , and 3 if people heavily meet where they say bigger than 6 . We expect that less financial satisfaction should increase the desire for equality.

The second variable is about religiosity. It equals 1 if individuals religious (yes), and zero otherwise. We expect that religious people do not support redistribution. The third variable is political ideology. This variable is represented by a political spectrum that varies from 1 to 10 . Individuals are seen as mainly leftist if they report a value that less than 5. Similarly, people are seen as mostly centrist if they indicate a value that equals 5 or 6 . Finally, individuals are seen as heavily rightist if they report a value that bigger than 5 . We expect

2 As Fullerton and Xu (2016, p. 23) states, recoding ordered variables does not affect the coefficient. Strömberg (1996) shows this fact by simulation (in Table 1). 
that leftist people will support equality more than centrist or rightist individuals do.

The fourth variable relates to beliefs about the sources of success in life. This variable also varies on 1 to 10 scale. We have recoded this variable as 1 if individuals report a value less than 5 . These people mainly believe in that work brings success in life. If people say 5 or 6 , we have recoded original variable as 2. These individuals can be seen as neutral and indifferent. Other people, who say a value bigger than 6 , have been recoded as 3 . They believe that the things that bring success in life are luck, social network and family background. We expect that individuals who believe that work is the source of achievement will also oppose redistribution.

The last variable in this category shows the position of people in income distribution. This variable, too, varies from 1 to 10 . It has been recoded as 1 if individuals report a value less than 5 , as 2 if individuals indicate a value that equals 5 or 6 , and as 3 if people report a value bigger than 6 . We expect that individuals who are in the bottom part of distribution vote for an equal world. Note that the source of success and region variables have not been given in the survey for 2001.

In addition to the previous theoretical explanation about preference for redistribution, we have added some extra variables following Garcia-Valinas et al. (2007). They call these variables as "social capital" indicators. These variables represent the level of trust of individuals related to armed force, legal system/law, press, labour unions, police, parliament, public services, big companies, European Union (for 2001, United Nations), and government. All original variables vary from 1 to 4 . We have recoded 1 (entirely trust) and 2 (little trust) values as 1 . This means that individuals trust corresponding institutions.

To estimate the determinants of preferences for redistribution, we have run ordered logistic regression by using our dependent and independent variables. Now, we will present briefly ordered logistic regression model. Let $i$ and $j$ represent individuals and outcome categories, respectively, $i=1,2, \ldots, N$ and $j=1,2, \ldots, J$. We can define our dependent variable, $y^{*}$, as latent variable as follows,

$$
y_{i}^{*}=\mathbf{x}_{i} \beta+\epsilon_{i}
$$

where $i$ is observation, $\mathbf{x}$ is a row vector of covariates for individual $i, \beta$ is column vector of coefficients to be estimated, and $\epsilon$ is error term. $y_{i}=m$ if $\tau_{m-1} \leq$ $y_{i}^{*}<\tau_{m}$ for $m=1$ to $J$ where cut-points $\tau_{1}$ through $\tau_{J-1}$ are estimated. The probability of $y=m$ for a given value of the $x$ 's corresponds to the region of the distribution where $y^{*}$ falls between $\tau_{m-1}$ and $\tau$ : 


$$
\operatorname{Pr}(y=m \mid \mathbf{x})=\operatorname{Pr}\left(\tau_{m-1} \leq y^{*}<\tau_{m} \mid \mathbf{x}\right) .
$$

Substituting $\mathbf{x} \beta+\epsilon$ for $y^{*}$ gives

$$
\operatorname{Pr}(y=m \mid \mathbf{x})=F\left(\tau_{m}-\mathbf{x} \beta\right)-F\left(\tau_{m-1}-\mathbf{x} \beta\right),
$$

where $F$ is cumulative distribution function for $\epsilon$. In the ordered logit model, $F$ is the logistic distribution. Ordinal logit model can be interpreted using odds ratios. Therefore, we have reported the estimation results as odds ratios.

\section{Findings}

Estimation results are given in Table 1 and Table 2. The effects of traditional determinants of preferences for redistribution are shown in Table 1. Besides, estimation results for trust variables with same control variables as in the first estimation (marital status, sex, age, employment status and education) are given in Table 2.

Marginal effects of some variables in the respective estimation on outcome probability are presented in Figure 1 and Figure. Beside separate estimations for each year, we have pooled data and have run the model. In all estimations, we have assumed that parallel regression assumption is not violated.

According to the estimation results in Table 1, for people who are dissatisfied with their households' financial situation, the odds of high dependent variable (opponent of equality) versus combined neutral/indifferent and low (proponent of equality) are 0.604 for 1990 and 0.707 for 2011 times smaller than moderately and substantially satisfied individuals, given the other variables are held constant. That is to say; such persons do support redistribution. This is not surprising. The severe financial situation makes individuals more risk-averse. Those people will consider redistribution as insurance and vote for in favour of redistribution. This variable complies with previous findings. 
Table 1: Estimation results for preferences for redistribution.

\begin{tabular}{lcccccc}
\hline \hline & $\mathbf{1 9 9 0}$ & $\mathbf{1 9 9 6}$ & $\mathbf{2 0 0 1}$ & $\mathbf{2 0 0 7}$ & $\mathbf{2 0 1 1}$ & Pooled \\
\hline Unsatisfied household & $0.604^{* * *}$ & 0.979 & $0.576^{* * *}$ & 0.976 & $0.707 * *$ & $0.683^{* * *}$ \\
financial situation & $(0.102)$ & $(0.131)$ & $(0.048)$ & $(0.172)$ & $(0.122)$ & $(0.038)$ \\
& 1.101 & $1.499 * * *$ & $1.241^{* *}$ & 0.897 & 0.998 & $1.150^{* *}$ \\
Religious & $(0.198)$ & $(0.206)$ & $(0.134)$ & $(0.155)$ & $(0.173)$ & $(0.072)$ \\
& $0.403 * * *$ & $0.511^{* * *}$ & $0.692^{* * *}$ & 0.835 & $0.568 * * *$ & $0.639^{* * *}$ \\
Political ideology & $(0.081)$ & $(0.075)$ & $(0.0759$ & $(0.131)$ & $(0.089)$ & $(0.040)$ \\
(leftist) & 0.973 & 1.145 & & $0.487 * * *$ & $0.394 * * *$ & \\
Source of success & $(0.150)$ & $(0.133)$ & & $(0.061)$ & $(0.047)$ & \\
(hard work) & 0.904 & 0.646 & 0.930 & $1.509 *$ & 0.925 & 0.906 \\
& $(0.251)$ & $(0.183)$ & $(0.130)$ & $(0.356)$ & $(0.231)$ & $(0.085)$ \\
Unemployed & 0.762 & 1.075 & 0.944 & 0.860 & 0.898 & 0.913 \\
& $(0.140)$ & $(0.147)$ & $(0.106)$ & $(0.143)$ & $(0.130)$ & $(0.054)$ \\
Income distribution & Yes & Yes & No & Yes & Yes & No \\
\hline Region dummy & & & & & & Yes \\
Year dummy & 746 & 1,225 & 2,571 & 1,029 & 1,277 & 6,848 \\
$N$ & 0.044 & 0.031 & 0.020 & 0.040 & 0.072 & 0.018 \\
\hline Pseudo $R^{2}$ & & & & & & \\
\hline \hline
\end{tabular}

Exponentiated coefficients. Robust standard errors in parentheses. $* \mathrm{p}<0.010, * * \mathrm{p}<0.05, * * * \mathrm{p}<0.01$.

The second variable is religiosity. As we have stated in the earlier pages, it is expected that religious individuals will tend to oppose redistribution. Our findings on this variable confirm this expectation. Except 2007 and 2011, for people who are religious, the odds of supporting inequality versus being neutral/indifferent and support equality are 1.101, for 1990 , and 1.150 , for pooled, times higher than not religious and atheists, given the other variables are held constant. Therefore, as previous estimations have shown, our estimation also confirms that religious individuals are in favour of more income differences between people as incentives.

The third variable is political ideology. We know from the political literature that leftist individuals are in favour of equality. Indeed, for mainly leftwing people, the odds of supporting inequality versus being neutral/indifferent and proponent of equality are 0.403 , for 1990 , and 0.568 , for 2011 , times lower than who are centrist or mainly rightist, given the other variables are held constant. There have been relatively centrist and rightist individuals in Turkey for many years. Thus, in a hypothetical referendum that is conducted for more redistributive tax and transfer system, no might be the result of the referendum with high probability. 
Figure 1. Marginal effects of some variables on outcome probability.
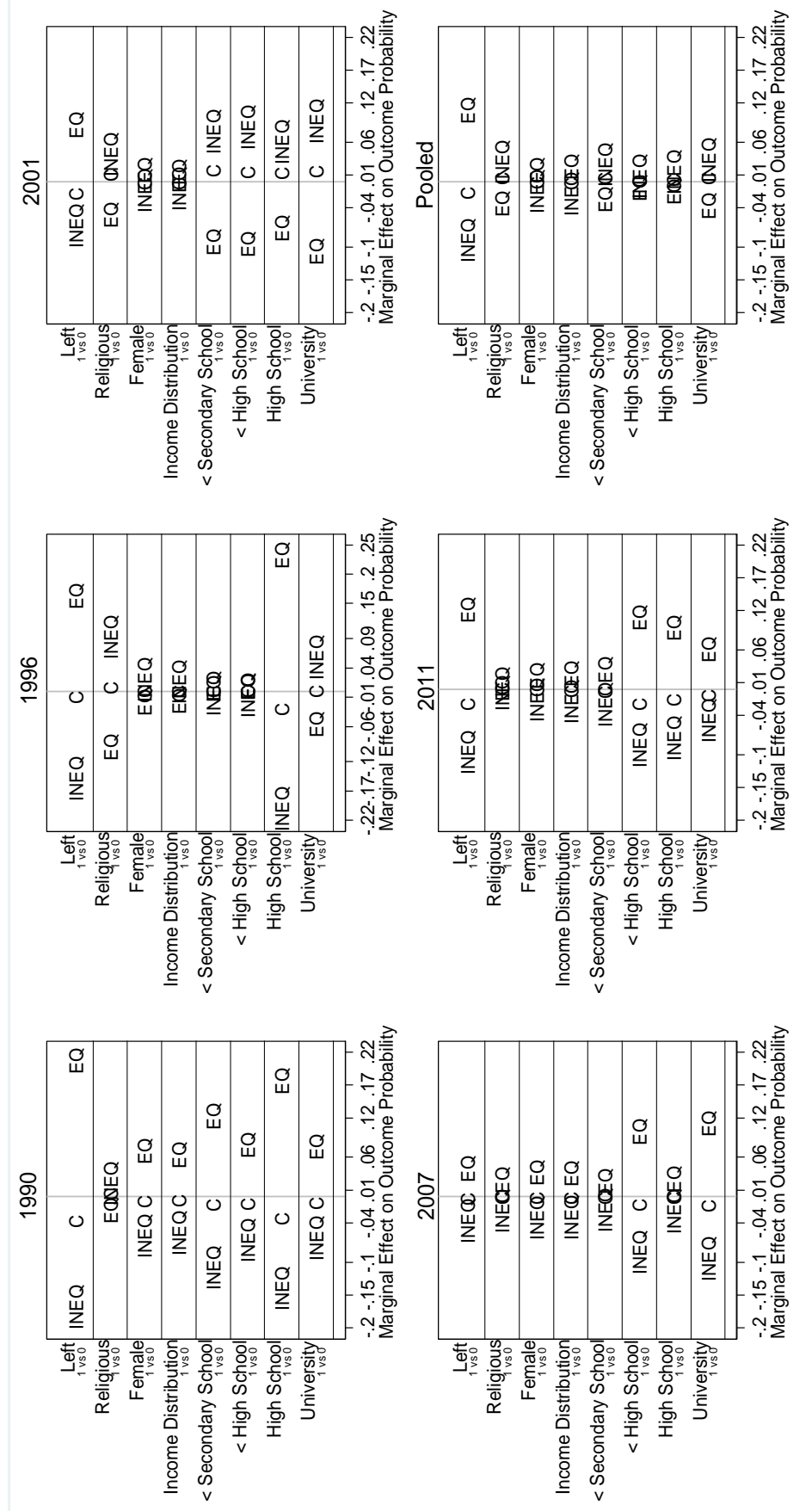
The fourth variable indicates individuals' beliefs about the sources of success in life. Unexpected results have appeared in this variable; we have expected that individuals who believe hard work brings success should oppose redistribution because they hope to move upward of income distribution in the future. This is the prospect of upward mobility hypothesis, and we have failed to support it. Except 1996, for individuals who believe mainly in hard work, the odds of promoting inequality versus being neutral/indifferent and proponent of equality lower than who are neutral/indifferent and believe in mostly luck and connections.

The next variable is the employment status of individuals. Unemployed people are more vulnerable to adverse events than employed and self-employed individuals are. They have little or no income, except unemployment insurance benefits. Therefore, it is usually expected that those people will be in favour of redistribution, at least in the short-run. Because if individuals hope to find a new job shortly, then they might be more likely oppose to redistribution because of the prospect of upward mobility. As we expected, except 2007, unemployed individuals tend to support an equal income distribution in society.

Finally, the last variable in the first estimation represents where individuals are in income distribution. The standard approach to preferences for redistribution predicts that people, who are below the mean income, especially when the median income is below the average income, will support redistribution. Except 1996, for those who mainly are in the lower part of income distribution, the odds of promoting inequality versus being neutral/indifferent and proponent of equality are 0.762 , for 1990 , and 0.898 , for 2011 , times lower than who is in the centre and mainly in the upper part of income distribution.

In addition to the odds ratios, we have calculated marginal effects at means of some variables on outcome probabilities. These marginal effects are given in Figure 1 for the first estimation. Figure 1 renders apparently the effects of three variables from the first estimation and two control variables. Being leftist decreases the probability of being a proponent of inequality approximately 0.20 in 1990. Similarly, being female increases the being supporter of equality nearly 0.02 . Generally, except 2001, individuals in all education level support equality when they compare uneducated people. Marginal effects describe the effect of independent variables on outcome probability in the more straightforward way. 
Table 2: Estimation results for preferences for redistribution with trust variables

\begin{tabular}{|c|c|c|c|c|c|c|}
\hline & 1990 & 1996 & 2001 & 2007 & 2011 & Pooled \\
\hline Armed forces & $\begin{array}{l}1.432 \\
(0.436)\end{array}$ & $\begin{array}{l}1.409 \\
(0.306)\end{array}$ & $\begin{array}{l}0.896 \\
(0.114)\end{array}$ & $\begin{array}{l}1.459 * \\
(0.300)\end{array}$ & $\begin{array}{l}0.996 \\
(0.162)\end{array}$ & $\begin{array}{l}1.038 \\
(0.075)\end{array}$ \\
\hline Justice system & $\begin{array}{l}0.873 \\
(0.178)\end{array}$ & $\begin{array}{l}1.002 \\
(0.130)\end{array}$ & & $\begin{array}{l}0.748 \\
(0.134)\end{array}$ & $\begin{array}{l}0.767 \\
(0.128)\end{array}$ & \\
\hline Press & $\begin{array}{l}0.736^{*} \\
(0.136)\end{array}$ & $\begin{array}{l}0.793 * * \\
(0.093)\end{array}$ & $\begin{array}{l}1.018 \\
(0.093)\end{array}$ & $\begin{array}{l}1.161 \\
(0175)\end{array}$ & $\begin{array}{l}1.374 * * \\
(0.189)\end{array}$ & $\begin{array}{l}0.994 \\
(0.053)\end{array}$ \\
\hline Labour unions & $\begin{array}{l}0.774 \\
(0.147)\end{array}$ & $\begin{array}{l}0.800 * \\
(0.092)\end{array}$ & $\begin{array}{l}0.893 \\
(0.079)\end{array}$ & $\begin{array}{l}0.943 \\
(0.138)\end{array}$ & $\begin{array}{l}0.866 \\
(0.117)\end{array}$ & $\begin{array}{l}0.872 * * * \\
(0.046)\end{array}$ \\
\hline Police & $\begin{array}{l}1.066 \\
(0.243)\end{array}$ & $\begin{array}{l}1.403 * * \\
(0.186)\end{array}$ & $\begin{array}{l}1.351^{* * * *} \\
(0.135)\end{array}$ & $\begin{array}{l}1.122 \\
(0.197)\end{array}$ & $\begin{array}{l}0.966 \\
(0.171)\end{array}$ & $\begin{array}{l}1.182 * * * \\
(0.071)\end{array}$ \\
\hline Parliament & $\begin{array}{l}1.589 * * \\
(0.357)\end{array}$ & $\begin{array}{l}0.947 \\
(0.115)\end{array}$ & $\begin{array}{l}1.177 * \\
(0.111)\end{array}$ & $\begin{array}{l}0.874 \\
(0.150)\end{array}$ & $\begin{array}{l}0.968 \\
(0.141)\end{array}$ & $\begin{array}{l}1.044 \\
(0.059)\end{array}$ \\
\hline Civil service & $\begin{array}{l}1.405 * \\
(0.285)\end{array}$ & $\begin{array}{l}0.763 * * \\
(0.094)\end{array}$ & $\begin{array}{l}0.915 \\
(0.086)\end{array}$ & $\begin{array}{l}1.094 \\
(0.184)\end{array}$ & $\begin{array}{l}0.899 \\
(0.133)\end{array}$ & $\begin{array}{l}0.913 \\
(0.052)\end{array}$ \\
\hline Major companies & $\begin{array}{l}1.305 \\
(0.269)\end{array}$ & $\begin{array}{l}1.373 * * * \\
(0162)\end{array}$ & $\begin{array}{l}1.135 \\
(0.098)\end{array}$ & $\begin{array}{l}1.323 * \\
(0.204)\end{array}$ & $\begin{array}{l}1.392 * * \\
(0.185)\end{array}$ & $\begin{array}{l}1.267 * * * \\
(0.067)\end{array}$ \\
\hline $\mathrm{EU}$ & $\begin{array}{l}1.019 \\
(0.182)\end{array}$ & $\begin{array}{l}1.054 \\
(0.122)\end{array}$ & $\begin{array}{l}1.025 \\
(0.087)\end{array}$ & $\begin{array}{l}1.332 * \\
(0.212)\end{array}$ & $\begin{array}{l}1.091 \\
(0.144)\end{array}$ & $\begin{array}{l}1.052 \\
(0.054)\end{array}$ \\
\hline Government & $\begin{array}{l}0.763 \\
(0.165)\end{array}$ & $\begin{array}{l}1.282 * \\
(0.164)\end{array}$ & $\begin{array}{l}0.178 * \\
(0.117)\end{array}$ & $\begin{array}{l}0.995 \\
(0.181)\end{array}$ & $\begin{array}{l}1.379 * \\
(0.236)\end{array}$ & $\begin{array}{l}1.140 * \\
(0.0699\end{array}$ \\
\hline Region dummy & Yes & Yes & No & Yes & Yes & No \\
\hline Year dummy & & & & & & Yes \\
\hline$N$ & 658 & 1,401 & 2,465 & 1,049 & 1,276 & 6,849 \\
\hline Pseudo $R^{2}$ & 0.040 & 0.027 & 0.010 & 0.031 & 0.052 & 0.012 \\
\hline
\end{tabular}

Exponentiated coefficients. Robust standard errors in parentheses. * $\mathrm{p}<0.010, * * \mathrm{p}<0.05, * * * \mathrm{p}<0.01$.

Now, we turn to second estimation results. To avoid high collinearity, we have not added variables that we have used in the first estimation except control variables. Hence, independent variables in the second estimation represent political and social stances. And this influences views of individuals towards institutions. People who trust armed forces and police tend to support income differences between individuals when they are compared with who does not trust these institutions. This has not surprised us. We believe in that people who trust police enforces place themselves on the right of the political spectrum in Turkey. Same general support for income differences has been found for trust in the press, major companies, European Union, and government. 
Figure 2. Marginal effects of trust variables on outcome probability.
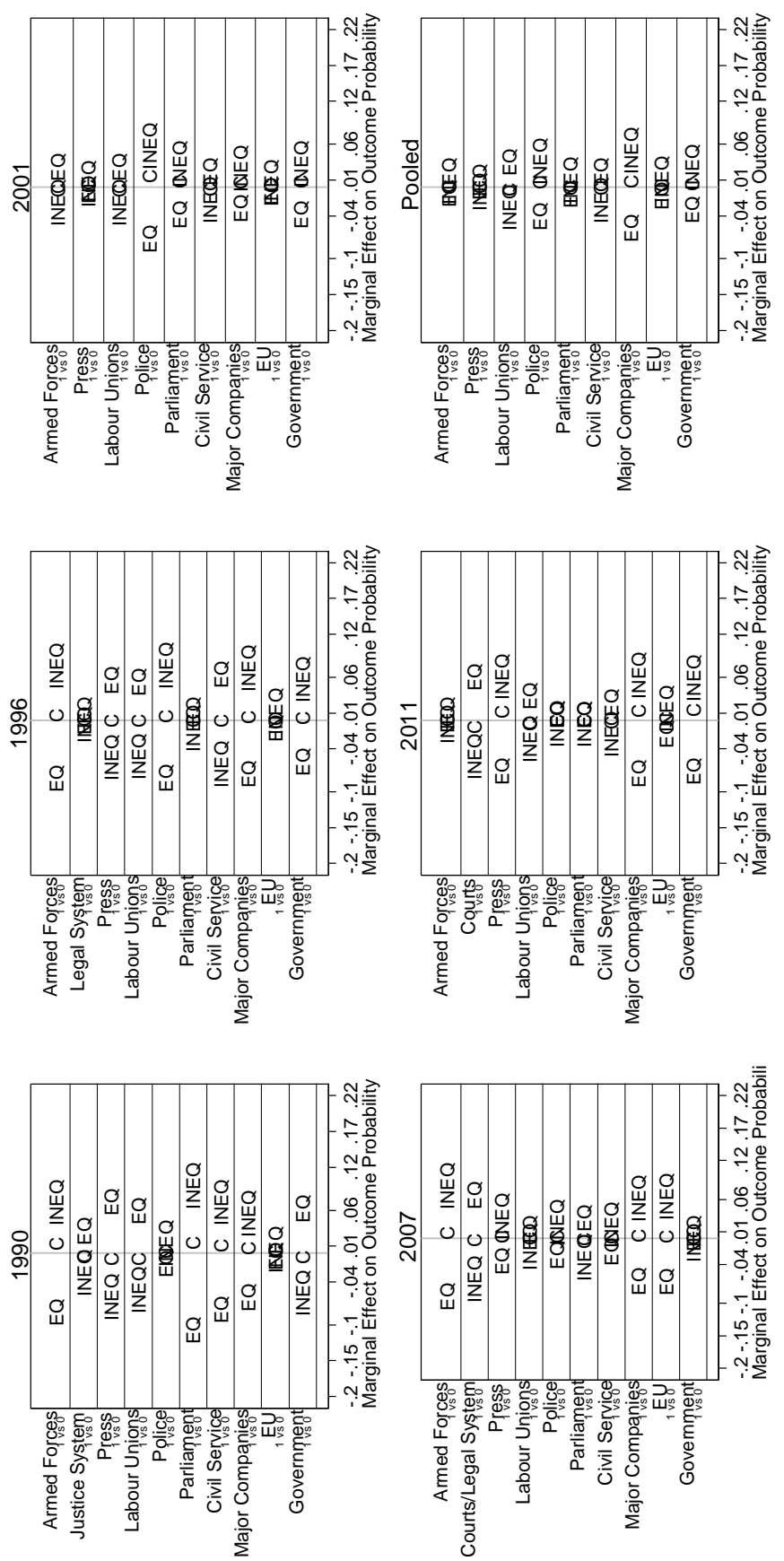
Three of these variables are particularly striking; armed forces, police and major companies. These variables have the highest impact on the preferences for redistribution in the negative sense. We are in doubt about the interrelation between these variables and religiosity, nationalism and capitalist behaviours.

People who trust labour unions support the equal income distribution when they are compared individuals who do not trust these institutions. We have been expecting this result. Likewise, trusting justice system might indicate the desire of an equal society. Except 1990 and 2001, people who trust parliament tend to support equality. For example, for individuals who trust justice system, the odds of supporting inequality versus being neutral/indifferent and proponent of equality are 0.873 , for 1990 , and 0.767 , for 2011 , times lower than individuals who do not trust the justice system. Corresponding values for people who trust labour unions are 0.774 and 0.866 , respectively. Marginal effects of all these variables can be found in Figure 2.

\section{Conclusion}

Income inequality is a highly debated topic in recent years. It has been rising in the western world and scholars has been trying to explain this increment. Even if the explanations broadly focus on historical development differences, top income, education, inheritance and intergenerational mobility, attitudes towards income inequality are also the critical side of the income inequality debate. In the modern world, people choose their representatives by voting. Elected politicians develop policies aimed at primarily their voters. The perception of inequality in individuals' mind and the factors, which affect this perception, become relevant for decision makers. To this end, this study has tried to reveal factors that influence preferences for redistribution and have shaded light on which factors essential in Turkey.

At first glance, it seems like economic factors are sole determinants that explain preferences for redistribution. However, it is seen that religion is crucial. Thus, policymakers might use religion to affect voters' perception of income inequality. Religious denominations also play important roles in this setting. The members of religious denominations look after each other, and their vulnerability to an adverse event is insured in a sense. However, people might be abused by this denomination. Therefore, governments cannot be substituted by religious denominations to reduce income differences. And another equally important factor is political ideology. The political ideology of individuals might evolve. However, it is not so easy to change political ideology of individuals. It is a resilient factor. We have also seen that reliance on institutions reflects critical 
sings about preferences for redistribution. Therefore, improving institutional confidence is vital for an equal world.

\section{References}

Alesina, A. and G.-M. Angeletos (2005), "Fairness and redistribution", American Economic Review 95 (4), 960-980.

Alesina, A. and N. Fuchs-Schündeln (2007), "Goodbye Lenin (or not?): The effect of communism on people", American Economic Review 97 (4), 1507-1528.

Alesina, A. and E. Glaeser (2005), Fighting Poverty in the US and Europe - A World of Difference. The Rodolfo De Benedetti Lecture Series. Oxford University Press.

Alesina, A. and E. La Ferrara (2005), "Preferences for redistribution in the land of opportunities", Journal of Public Economics 89 (5-6), 897-931.

Alesina, A. and D. Rodrik (1994), "Distributive politics and economic growth", The Quarterly Journal of Economics 109 (2), 465-490.

Alesina, A., B. Sacerdote, and E. Glaeser (2001), “Why doesn't the United States have a Europeanstyle welfare state?", Brookings Papers on Economic Activity (2).

Alesina, A. F. and P. Giuliano (2009), “Preferences for redistribution”, Working Paper 14825, National Bureau of Economic Research.

Arıkan, G. (2013), "Values, religiosity and support for redistribution and social policy in Turkey", Turkish Studies 14 (1), 34-52.

Benabou, R. and E. A. Ok (2001), "Social mobility and the demand for redistribution: The POUM hypothesis", The Quarterly Journal of Economics 116 (2), 447-487.

Bénabou, R. and J. Tirole (2006), "Belief in a just world and redistributive politics", The Quarterly Journal of Economics 121 (2), 699-746.

Clark, A. E. and C. D'Ambrosio (2015), "Attitudes to income inequality: Experimental and survey evidence", A. B. Atkinson and F. Bourguignon (Eds.), Handbook of Income Distribution, Volume 2, pp. 1147-1208. Elsevier.

Corneo, G. and H. P. Grüner (2002), "Individual preferences for political redistribution", Journal of Public Economics 83 (1), 83-107.

Costa-Font, J. and F. Cowell (2015), "Social identity and redistributive preferences: A survey", Journal of Economic Surveys 29 (2), 357-374.

Dahlberg, M., K. Edmark, and H. Lundqvist (2012), "Ethnic diversity and preferences for redistribution", Journal of Political Economy 120 (1), 41-76.

Fehr, E. and K. M. Schmidt (1999), "A theory of fairness, competition, and cooperation", The Quarterly Journal of Economics 114 (3), 817-868.

Fong, C. (2001), "Social preferences, self-interest, and the demand for redistribution", Journal of Public Economics 82 (2), 225-246. 
Fullerton, A. S. and J. Xu (2016), Ordered Regression Models - Parallel, Partial, and Non-Parallel Alternatives, CRC Press.

García-Valiñas, M. A., R. F. Llera, and B. Torgler (2007), "Preferences towards redistribution and equality: How important is social capital?", J. Bishop and Y. Amiel (Eds.), Inequality and Poverty, Volume 14 of Research on Economic Inequality, pp. 31-47. Emerald Group Publishing Limited.

Guillaud, E. (2008), "Preferences for redistribution: a European comparative analysis", PSE Working Papers n2008-41.

Guillaud, E. (2013), "Preferences for redistribution: an empirical analysis over 33 countries", The Journal of Economic Inequality 11 (1), 57-78.

Hirschman, A. O. and M. Rothschild (1973), "The changing tolerance for income inequality in the course of economic development: With a mathematical appendix", The Quarterly Journal of Economics 87 (4), 544-566.

Isaksson, A.-S. and A. Lindskog (2009), "Preferences for redistribution-a country comparison of fairness judgements", Journal of Economic Behavior \& Organization 72 (3), 884-902.

Karayel, A. (2015), "Income inequality tolerance and preferences for redistribution in Turkey", European Journal of Economics and Business Studies 3 (1), 98-105.

Karayel, A. (2016), "Attitudes to income inequality and preferences for redistribution in Turkey. H. M. Bilgin, H. Danış, E. Demir, and U. Can (Eds.), Business Challenges in the Changing Economic Landscape - Vol. 1: Proceedings of the 14th Eurasia Business and Economics Society Conference, pp. 339-354. Springer.

Keely, L. C. and C. M. Tan (2008), “Understanding preferences for income redistribution”, Journal of PublicEconomics 92(5-6), 944-961.

Luttmer, E. F. P. (2001), "Group loyalty and the taste for redistribution", Journal of Political Economy $109(3), 500-528$.

Luttmer, E. F. P. and M. Singhal (2011), "Culture, context, and the taste for redistribution", American Economic Journal: Economic Policy 3 (1), 157-79.

Meltzer, A. H. and S. F. Richard (1981), "A rational theory of the size of government", Journal of Political Economy 89(5), 914-927.

Milanovic, B. (2000), "The median voter hypothesis, income inequality, and income redistribution: an empirical test with the required data", European Journal of Political Economy 16(3), 367410.

Neher, F. (2011), "Preferences for redistribution across the world", http://www.wiwiss.fuberlin.de/en/fachbereich/vwl/corneo/dp/Preferences_for_Redistribution_around_the_Worl d_VDiss.pdf (02.05.2017).

Neustadt, I. (2011), "Do religious beliefs explain preferences for income redistribution? Experimental evidence", CESifo Economic Studies 57 (4), 623-652.

Neustadt, I. and P. Zweifel (2009), "Economic Well-Being, Social Mobility, and Preferences for Income Redistribution: Evidence from a Discrete Choice Experiment", SOI-Working Papers 0909, Socioeconomic Institute - University of Zurich.

Piketty, T. (1995), "Social mobility and redistributive politics", The Quarterly Journal of Economics $110(3), 551-584$.

Piketty, T. (1996), "The politics of redistribution - recent developments and research perspectives", Boston. McArthur Foundation Costs of Inequality Project. 
Rainer, H. and T. Siedle (2008), "Subjective income and employment expectations and preferences for redistribution", Economics Letters 99(3), 449-453.

Roberts, K. W. (1977), "Voting over income tax schedules”, Journal of Public Economics 8 (3), 329340.

Rodrigiuez, F. C. (1999), "Does distributional skewness lead to redistribution? Evidence from the United States", Economics \& Politics 11 (2), 171-199.

Roemer, J. E. and K. V. d. Straeten (2005), "Xenophobia and the size of the public sector in France: A politico-economic analysis", Journal of Economics 86(2), 95-144.

Romer, T. (1975), "Individual welfare, majority voting, and the properties of a linear income tax", Journal of Public Economics 4 (2), 163-185.

Strömberg, U. (1996), "Collapsing ordered outcome categories: A note of concern", American Journal of Epidemiology 144(4), 421-424. 